\title{
Stargazin Reduces Desensitization and Slows Deactivation of the AMPA-Type Glutamate Receptors
}

\author{
Avi Priel, ${ }^{1}$ Alexander Kolleker, ${ }^{2}$ Gai Ayalon, ${ }^{1}$ Moshe Gillor, ${ }^{1}$ Pavel Osten, ${ }^{2}$ and Yael Stern-Bach ${ }^{1}$ \\ ${ }^{1}$ The Institute of Basic Dental Sciences, The Hebrew University-Hadassah Dental School, Jerusalem 91120, Israel, and ${ }^{2}$ Department of Molecular \\ Neurobiology, Max Planck Institute for Medical Research, 69120 Heidelberg, Germany
}

The AMPA-type glutamate receptors mediate the majority of the fast excitatory synaptic transmission and critically contribute to synaptic plasticity in the brain, hence the existence of numerous trafficking proteins dedicated to regulation of their synaptic delivery and turnover. Stargazin (also termed $\gamma 2$ ) is a member of a recently identified protein family termed transmembrane AMPA receptor regulatory proteins (TARPs). TARPs physically associate with AMPA receptors and participate in their surface delivery and anchoring at the postsynaptic membrane. Here, we report that next to its trafficking roles, stargazin may also act as a positive allosteric modulator of AMPA receptor ion channel function. Coexpression of stargazin with AMPA receptor subunits, either in Xenopus oocytes or in human embryonic kidney 293 cells, significantly reduced receptor desensitization in response to glutamate. Receptor deactivation rates were also slowed, and the recovery from desensitization was accelerated. Structurally, based on the data showing a tight correlation between desensitization and the stability of the AMPA receptor intradimer interface, we propose that binding of stargazin may stabilize the receptor conformation. Functionally, our data suggest that AMPA receptors complexed with stargazin (and possibly also with other TARPs) at the postsynaptic membrane are significantly more responsive to synaptically released glutamate compared with AMPA receptors lacking stargazin/TARP interaction. The putative existence of such two states of synaptic AMPA receptors, with and without stargazin/TARP binding, may provide a novel mechanism for regulation of excitatory synaptic strength during development and/or in synaptic plasticity in the adult brain.

Key words: AMPA receptors; stargazin; trafficking; desensitization; patch clamp; heterologous expression

\section{Introduction}

The AMPA receptor channel is a tetrameric assembly formed by different combinations of four subunits termed glutamate receptors 1-4 (GluR1-4) (or GluR-A through GluR-D) (Dingledine et al., 1999). The subunit composition affects the electrophysiological properties of the receptors and determines their interactions with various trafficking proteins. These subunit-specific protein interactions are believed to be especially important in the regulation of AMPA receptor transport during different forms of synaptic plasticity (Zamanillo et al., 1999; Shi et al., 2001). On the other hand, two types of trafficking proteins were reported to interact with all (or at least three) AMPA receptor subunits: Narp, a secreted immediate-early gene product that binds to the extracellular portions of the subunit molecule (O’Brien et al., 1999), and the transmembrane AMPA receptor regulatory proteins (TARPs) stargazin $/ \gamma 2, \gamma 3, \gamma 4$, and $\gamma 8$ (Tomita et al., 2003). TARPs are four-transmembrane proteins with a weak homology

\footnotetext{
Received Nov. 26, 2004; revised Jan. 7, 2005; accepted Jan. 28, 2005.

This work was supported by grants from The German Israeli Foundation for Scientific Research and Development (733-60-13/2002 to Y.S.-B. and P.0.) and from the Bernard Katz Minerva Center for Cell Biophysics (Y.S.-B.). A.P. is a recipient of the David Kline Prize of Excellence from the Canadian Friends of The Hebrew University. We thank Peter H. Seeburg for support.

Correspondence should be addressed to Dr. Yael Stern-Bach, The Institute of Basic Dental Sciences, The Hebrew University-Hadassah Dental School, Jerusalem 91120, Israel. E-mail: yealb@cc.huji.ac.il.

G. Ayalon's present address: Department of Cell Biology, Duke University Medical Center, Durham, NC 27710 DOI:10.1523/JNEUROSCI.4834-04.2005

Copyright $\odot 2005$ Society for Neuroscience $\quad 0270-6474 / 05 / 252682-05 \$ 15.00 / 0$
}

to the $\gamma$ subunits of muscle voltage-dependent $\mathrm{Ca}^{2+}$ channels (VDCCs) (Burgess et al., 1999; Klugbauer et al., 2000). Strikingly, a spontaneous loss of function of stargazin in a mouse mutant (Letts et al., 1998) resulted in failure of synaptic surface expression of AMPA receptors in cerebellar granule cells, in addition to other phenotypic manifestations (Hashimoto et al., 1999; Chen et al., 2000). Additional work demonstrated that TARPs associate directly with the AMPA receptors and enhance their delivery as well as targeting to the synaptic membrane (Chen et al., 2000; Schnell et al., 2002; Cuadra et al., 2004). At the synaptic surface, TARPs may remain complexed with the receptors and unbind only during receptor internalization (Tomita et al., 2004).

The transmembrane topology of TARPs raises an intriguing possibility that TARPs may also regulate AMPA receptor intrinsic functions. A tight binding of one or more TARP molecules per receptor channel may alter the receptor conformation or stabilize a specific conformational state (note that the stoichiometry of the TARP-AMPA receptor complex is presently unknown). Here, we investigated the effect of stargazin on AMPA receptor desensitization, because this feature of the ion channel function may be particularly susceptible to conformational regulation. AMPA receptor activation is quickly followed by closing of the ion channel, desensitization, although the receptor still binds neurotransmitter (for review, Jones and Westbrook, 1996). This state was proposed to result from an intradimer conformational rearrangement within the receptor molecule (Sun et al., 2002). We 
found that coexpression of stargazin with GluR1 or GluR2 indeed significantly reduced their desensitization in response to glutamate application in heterologous expression systems. This function of stargazin did not depend on interactions at the C-terminal postsynaptic density-95 (PSD-95)/Discs large/zona occludens-1 (PDZ)-binding motif or the neuronal isoform of protein interacting specifically with TC10 (nPIST) interaction site, thus supporting the notion that this effect is attributable to direct stargazin-AMPA receptor binding rather than receptor clustering. Moreover, deactivation rates of GluR1 were also slowed in the presence of stargazin, and receptor recovery from desensitization was accelerated. Based on these data, we propose that binding of stargazin, and possibly of other TARPs as well, serves as a native mechanism for regulating AMPA receptor ion channel function.

\section{Materials and Methods}

Constructs. GluR1 (flip isoform) in pBlueScript was obtained from S. F. Heinemann (Salk Institute, La Jolla, CA) and subcloned in pGEMHE for expression in oocytes. The GluR-A and GluR-B unedited form (R607Q), both flip isoforms (termed here GluR1 and GluR2), and enhanced green fluorescent protein (EGFP) in pRK5 were a gift from P. H. Seeburg (Max Planck Institute for Medical Research, Heidelberg, Germany). Stargazin $(\gamma 2)$ and VDCC subunit $\gamma 1$ were cloned from mouse cDNA. The coding sequence for EGFP (Clontech, Palo Alto, CA) was inserted into $\gamma 2$ at the BglII site (between residues 269 and 270). Untagged and tagged $\gamma 2$ were subcloned in pGEMHE by XbaI/HindIII and in pRK by XbaI/SalI. Deletions of the C-terminal four amino acids $(\gamma 2 \Delta \mathrm{PDZ})$ and residues 244 $283[\gamma 2 \Delta(244-283)]$ were done by PCR. EGFP, flanked by BglII sites, replaced the deleted residues in $\gamma 2 \Delta(244-283)$. The C-terminal 59 amino acids $(\gamma 2 \Delta 265-323)$ were removed by partial digest with $B g l \mathrm{II}$ and HindIII, maintaining the EGFP coding sequence.

Heterologous expression. Xenopus laevis oocytes were prepared and injected with cRNA as described previously (Ayalon and Stern-Bach, 2001). Human embryonic kidney 293 (HEK293) cells were grown in DMEM (Sigma, St. Louis, MO) supplemented with 10\% FCS, $100 \mathrm{U} / \mathrm{ml}$ penicillin, $0.1 \mathrm{mg} / \mathrm{ml}$ streptomycin, and $1 \mathrm{~mm}$ sodium pyruvate (Biological Industries, Beit-Haemek, Israel) at $37^{\circ} \mathrm{C}, 5 \% \mathrm{CO}_{2}$. Cells were plated on coverslips coated with poly-D-lysine $(0.1 \mathrm{mg} / \mathrm{ml}$; Sigma) in 12-well plates and $2 \mathrm{~h}$ later were transfected with the pRK5 plasmids containing the following constructs ( $1 \mu \mathrm{g}$ of DNA/coverslip at a 1:1 ratio): GluR1 or GluR2 with either EGFP or EGFP-tagged $\gamma 2, \gamma 2 \Delta$ PDZ, $\gamma 2 \Delta(265-323)$, or $\gamma 2 \Delta(244-283)$. Transfections were made using the calcium phosphate method or Polyfect (Qiagen, Hilden, Germany).

Electrophysiology. Two electrode voltage-clamp recordings on oocytes were done as described previously (Ayalon and Stern-Bach, 2001). To reduce receptor desensitization, glutamate was applied together with cyclothiazide (CTZ) (0.1 mm; Research Biochemicals, Natick, MA). Recordings in HEK293 cells were performed 24-48 h after transfection. Membrane currents were recorded under the outside-out configuration of the patch-clamp technique (Hamill et al., 1981; Priel and Silberberg, 2004) using the Axopatch 200B amplifier (Axon Instruments, Foster City, CA). Currents were digitized using a Digidata 1322A interface board and pClamp 8.1 software (Axon Instruments). The sampling frequency was set to $10 \mathrm{kHz}$, and the low-pass filter was set to $2 \mathrm{kHz}$. Patch electrodes were fabricated from borosilicate glass with a resistance of 2-5 $\mathrm{M} \Omega$. The extracellular solution contained the following (in $\mathrm{mM}$ ): 150 $\mathrm{NaCl}, 2.8 \mathrm{KCl}, 0.5 \mathrm{MgCl}_{2}, 2 \mathrm{CaCl}_{2}$, and 10 HEPES, adjusted to $\mathrm{pH} 7.4$ with $\mathrm{NaOH}$. The pipette solution contained the following (in $\mathrm{mM}$ ): 110 CsF, $30 \mathrm{CsCl}, 4 \mathrm{NaCl}, 0.5 \mathrm{CaCl}_{2}, 10 \mathrm{EGTA}$, and 10 HEPES, adjusted to $\mathrm{pH}$ 7.2 with $\mathrm{CsOH}$. For the rapid application of glutamate, solutions were applied from a double-barrel glass (theta tube) mounted on a piezoelectric translator (Burleigh, Fishers, NY) (Jonas, 1995). One barrel contained continuously flowing extracellular solution, and the other contained $3 \mathrm{~mm}$ glutamate solution. The patches were excised from the cells and positioned adjacent to the interface of the solutions flowing through the theta tubing. The digital-to-analog output from the computer inter- face was used to trigger the displacement and return of the piezoelectric translator, moving the solution interface over the patch. The speed of solution exchange was estimated by recording the open tip potentials with solutions of different ionic strengths after expelling the patch from the electrode. The $10-90 \%$ solution exchange was typically $<500 \mu$ s. Receptor desensitization was measured by applying $3 \mathrm{~mm}$ glutamate for 100 or $500 \mathrm{~ms}$, and the desensitization rate $\left(\tau_{\mathrm{des}}\right)$ was estimated by a single exponential fitting of the current decay starting from $95 \%$ of the peak to the baseline current. Deactivation rates were measured similarly for currents evoked by $1 \mathrm{~ms}$ of glutamate application. The recovery from desensitization was estimated with the two-pulse protocol in which a constant $100 \mathrm{~ms}$ application of $3 \mathrm{~mm}$ glutamate was followed by a test pulse applied in different time intervals. The paired pulses were separated by $10 \mathrm{~s}$ intervals to allow full recovery from desensitization. Because $\gamma 2$ mainly increases the proportional steady-state current, the ratio between the test $\left(I_{2}\right)$ and control $\left(I_{1}\right)$ currents was calculated using the formula $\left(I_{\text {peak }}-\right.$ $\left.I_{\text {steady-state }}\right)_{2} /\left(I_{\text {peak }}-I_{\text {steady-state }}\right)_{1}$, and the single exponential was fitted to the plot of ratios against time (Lerma, 1992). Data were analyzed using pClamp 8.1 software (Axon Instruments) and Origin 6.1 software (Origin Lab, Northampton, MA).

Cell-surface protein biotinylation. Oocyte surface biotinylation was done as described previously (Ayalon and Stern-Bach, 2001). For HEK293 cells, transfected cells grown in poly-D-lysine-coated $25 \mathrm{~cm}^{2}$ culture dishes were washed three times with ice-cold PBS supplemented with $1.0 \mathrm{mM} \mathrm{MgCl}_{2}$ and $0.5 \mathrm{~mm} \mathrm{CaCl}_{2}$ (PBSCM) and incubated for 15 min with $0.5 \mathrm{mg} / \mathrm{ml} \mathrm{EZ-link} \mathrm{Sulfo-NHS-SS-Biotin} \mathrm{(Pierce,} \mathrm{Rockford,} \mathrm{IL)}$ in cold PBSCM, pH 8.0, with gentle agitation at $4^{\circ} \mathrm{C}$. Cells were washed once and incubated for $10 \mathrm{~min}$ with a quenching buffer (192 mM glycine and $25 \mathrm{~mm}$ Tris in PBSCM). Next, cells were rinsed twice in cold PBS, collected, homogenized in lysis buffer (1\% Triton X-100, 20 mM HEPES, $\mathrm{pH} 7.4$, and $150 \mathrm{~mm} \mathrm{NaCl}$ ), and centrifuged. Supernatants (100 $\mu \mathrm{g}$ of total protein) were incubated with $50 \mu \mathrm{l}$ of $50 \%$ slurry of streptavidinSepharose (Pierce) overnight at $4^{\circ} \mathrm{C}$ and then washed three times with lysis buffer. Biotinylated proteins were eluted by $5 \mathrm{~min}$ boiling in SDSPAGE sample buffer, separated on $8 \%$ gel, and immunoblotted with rabbit polyclonal antibody to GluR1 (Chemicon, Temecula, CA) and to calnexin (endoplasmic reticulum protein, serving as a control for cell integrity; Stressgen, Sidney, British Columbia, Canada). Bands were visualized by the chemiluminescence protocol, scanned, and quantified using ImageJ software.

\section{Results}

Stargazin reduces GluR1 desensitization in Xenopus oocytes Consistent with previous studies (Chen et al., 2003; Tomita et al., 2004), coexpression of stargazin (Fig. 1A), but not of the VDCC subunit $\gamma 1$ (data not shown), strongly enhanced GluR1 wholecell currents in oocytes in a concentration- and time-dependent manner (note that because of strong receptor desensitization, recordings were done in the presence of the allosteric inhibitor of desensitization, CTZ) (Patneau et al., 1993). As reported previously (Chen et al., 2003), the potentiation of GluR1 currents was correlated with an increase in the GluR1 protein surface expression (Fig. $1 \mathrm{~B}$ ), a finding that is consistent with the proposed role of stargazin in the delivery of AMPA receptors to the cellular surface membrane (Chen et al., 2000). In addition, coexpression of stargazin caused a moderate increase in the total GluR 1 protein expression, possibly because of a reduced protein turnover of the receptor subunit bound with stargazin.

Strikingly, a comparison of GluR1 currents in the presence or absence of CTZ revealed that CTZ-mediated potentiation of GluR1 currents was significantly lower in oocytes coinjected with stargazin compared with oocytes injected with only GluR1 (Fig. $1 C$ ). These experiments were done with normalized GluR1 surface expression. Glutamate-evoked currents in oocytes injected with a large amount of GluR1 cRNA ( $5 \mathrm{ng}$ ) were compared with oocytes injected with a small amount of GluR1 (0.5 ng) together with stargazin. Under these conditions, GluR1 currents in the 

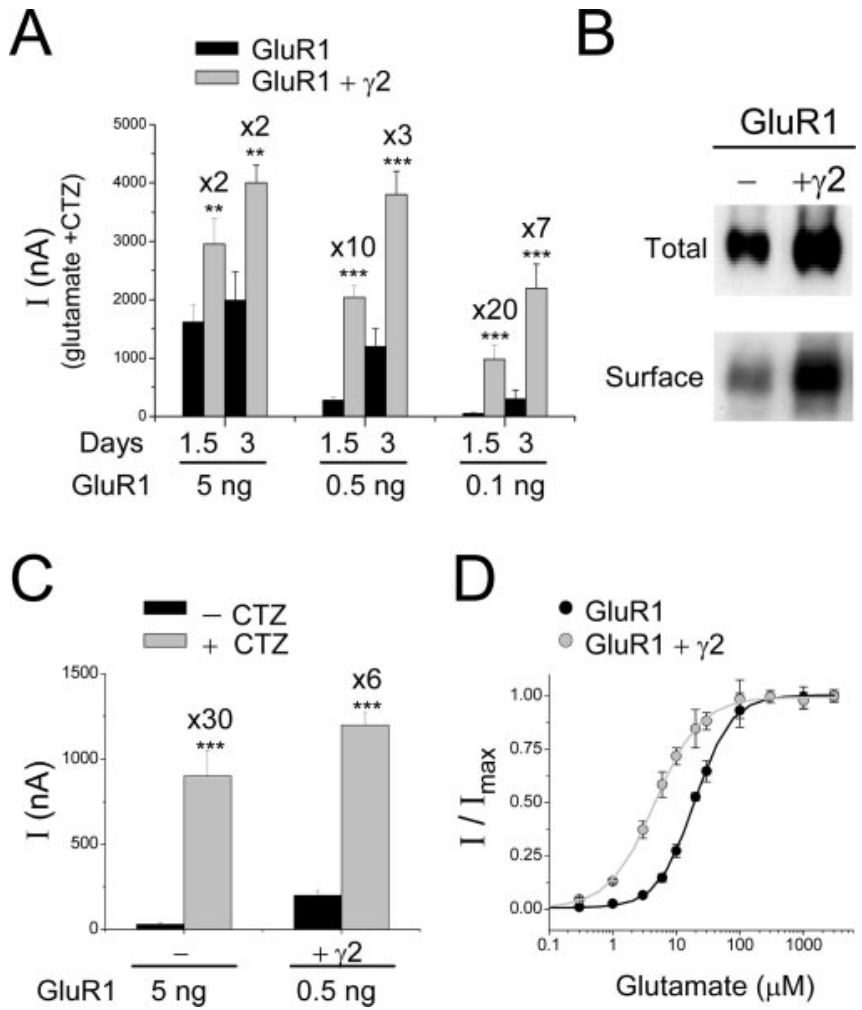

Figure 1. Stargazin $/ \gamma 2$ enhances surface expression and reduces desensitization of GluR1 in oocytes. $\boldsymbol{A}$, Enhancement of GluR1 whole-cell currents by $\gamma 2$ depends on the amount of cRNA injected and on the incubation time. GluR1 cRNA was injected at different amounts (0.1-5 $\mathrm{ng} /$ oocyte), as indicated, without (black bars) or with (gray bars; $1 \mathrm{ng} / 00$ cyte) $\gamma 2$ (RNA, and whole-cell currents in response to $1 \mathrm{~mm}$ glutamate plus $0.1 \mathrm{~mm}$ CTZ were measured 1.5 and $3 \mathrm{~d}$ after injection. In each case, enhancement in whole-cell current after coexpression with $\gamma 2$ is indicated above the gray bars $\left(n=14 ;{ }^{* *} p<0.01 ;{ }^{* * *} p<0.001\right)$. Similar results were obtained for GluR1 ( $5 \mathrm{ng}$ ) injected with 5 or $10 \mathrm{ng}$ of $\gamma 2$, indicating that $\gamma 2$ was not a limiting factor at these expression conditions. $\boldsymbol{B}$, Surface biotinylation assay (performed $2 \mathrm{~d}$ after injection) on oocytes injected with GluR1 $(0.5 \mathrm{ng})$ without $(-)$ or with $(+\gamma 2 ; 1 \mathrm{ng}) \gamma 2$ shows that $\gamma 2$ mainly enhances GluR1 surface expression and moderately increases total expression. Blots were exposed with anti-GluR1 antibody. C, CTZ enhancement of GluR1 whole-cell currents in response to $1 \mathrm{~mm}$ glutamate is lower for oocytes coinjected with $\gamma 2$. GluR1 $(5$ or $0.5 \mathrm{ng}$ ) was injected, as indicated, without $(-)$ or with $(+\gamma 2)$ stargazin. Currents were measured after $1.5 \mathrm{~d}$ without (black bars) or with (gray bars) CTZ. (TZ-dependent current enhancement is indicated above the gray bars. ${ }^{* *} p<0.001$. $\boldsymbol{D}$, Glutamate dose-response (with (TZ) measurements on oocytes injected with GluR1 ( $5 \mathrm{ng}$ ) alone (black circles) and GluR1 ( $0.5 \mathrm{ng}$ ) plus $\gamma 2$ $(1 \mathrm{ng})$ (gray circles). The maximum responses (at $3 \mathrm{~mm}$ glutamate) and $\mathrm{EC}_{50}$ values were $1090 \pm 160 \mathrm{nA}, 18.5 \pm 0.5 \mu \mathrm{m}$ (without $\gamma 2$ ) and $1400 \pm 120 \mathrm{nA}, 5.0 \pm 0.3 \mu \mathrm{m}$ (with $\gamma 2$ ), respectively $(n=6)$. At these conditions, responses to $3 \mathrm{~mm}$ glutamate of GluR1 $(0.5 \mathrm{ng})$ injected alone were $160 \pm 50 \mathrm{nA}$.

presence of CTZ were similar for both conditions (Fig. 1C, compare gray bars). However, the CTZ potentiation of GluR1 currents was 30 -fold without stargazin and only 6-fold with stargazin (Fig. 1C). Similarly, direct comparison of GluR1 currents in the absence of CTZ showed sevenfold larger currents for GluR1 plus stargazin compared with GluR1 alone (Fig. 1C, compare black bars). Furthermore, the glutamate $\mathrm{EC}_{50}$ value was significantly

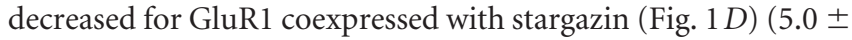
$0.3 \mu \mathrm{M}$ with and $18.5 \pm 0.5 \mu \mathrm{M}$ without stargazin). Such $\mathrm{EC}_{50}$ shift is reminiscent of the change in the $\mathrm{EC}_{50}$ value of the AMPA GluR3 mutant with abolished desensitization, GluR3(L507Y) (Stern-Bach et al., 1998). To test whether both the L-to-Y mutation and the effect of stargazin may act via the same mechanism, we tested the glutamate $\mathrm{EC}_{50}$ value of the corresponding GluR1(L497Y) mutant, with and without stargazin. In this case,
A GluR1 $\quad$ B $\quad$ GluR2
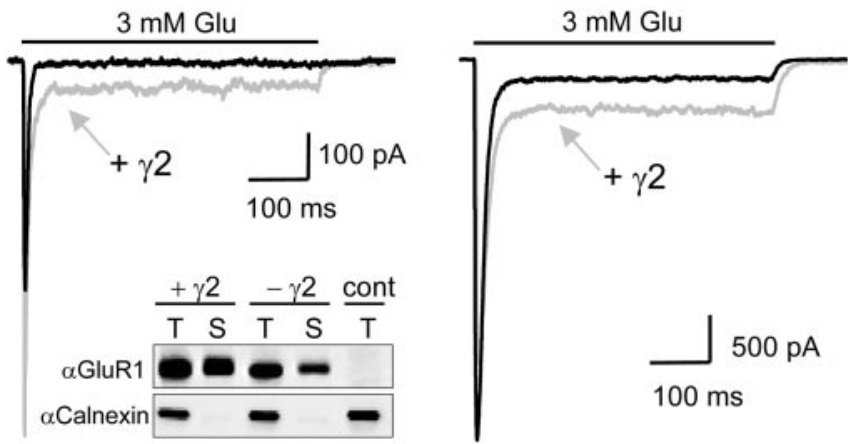

$100 \mathrm{~ms}$
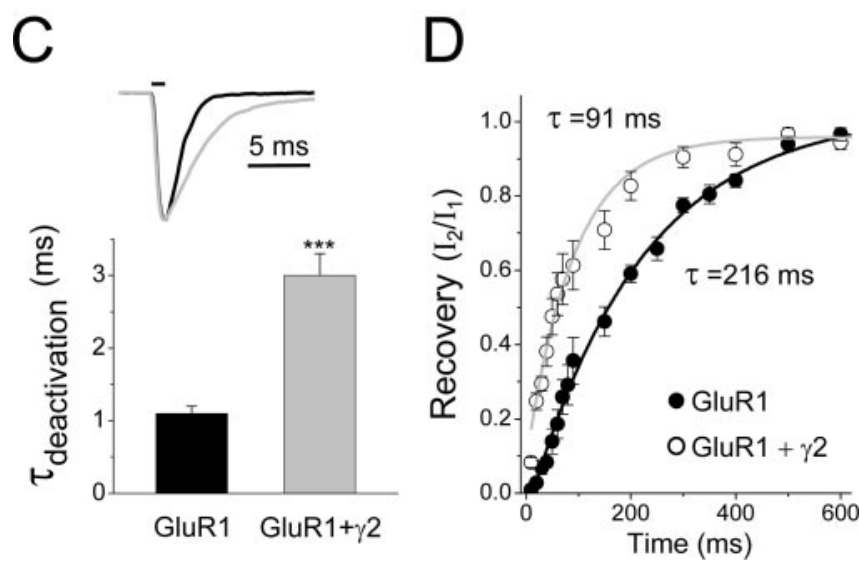

Figure 2. Stargazin $/ \gamma 2$ modifies the current profile of AMPA receptors expressed in HEK293 cells. $A, B$, Superimposed current traces (holding potential, $-60 \mathrm{mV}$ ) of outside-out patches of GluR1 $(\boldsymbol{A})$ and GluR2 $(\boldsymbol{B})$ without (black trace) or with (gray trace) EGFP-tagged $\gamma 2$. Similar results were obtained with untagged $\gamma 2$. $\boldsymbol{A}$, Inset, Western blot of total (T) and surface (S) GluR1 protein expressed with $(+\gamma 2)$ and without $(-\gamma 2) \gamma 2$ using the surface biotinylation assay [calnexin served as a control (cont) for cell integrity]. C, Deactivation rates in response to a $1 \mathrm{~ms}$ application of $3 \mathrm{~mm}$ glutamate of GluR1 expressed without (black bar) or with (gray bar) $\gamma 2$. Each bar is an average ( \pm SEM) of seven cells. ${ }^{* * *} p<0.001$. Superimposed representative normalized current traces are shown at the top. $D$, Desensitization recovery rates of GluR1 with and without $\gamma 2$ measured by two-pulse protocols and analyzed as described in Materials and Methods. Each point is an average ( \pm SEM) of five to seven cells.

coexpression of stargazin had no effect on the GluR1(L497Y) glutamate $\mathrm{EC}_{50}$ value $(3.8 \pm 0.2$ and $4.3 \pm 0.1 \mu \mathrm{M}$ with and without $\gamma 2$, respectively; data not shown), indicating that the mutation occluded the effect of stargazin. Together, these findings strongly suggest that stargazin, in addition to its effect on receptor trafficking, reduces glutamate-evoked desensitization of GluR1 receptors via a mechanism similar to the effects of either CTZ or the L-to-Y mutation.

\section{Stargazin acts as an allosteric modulator of AMPA receptor desensitization and deactivation in HEK293 cells}

To have better control over the measured AMPA receptor desensitization, GluR1 or GluR2 were expressed in HEK293 cells, and the recordings were done with the outside-out configuration of the patch-clamp technique combined with a fast perfusion system (see Materials and Methods). As shown in Figure $2 \mathrm{~A}$ (black trace), in a cell transfected with GluR1, application of $3 \mathrm{~mm}$ glutamate for $500 \mathrm{~ms}$ evoked a robust current (378 pA) that desensitized rapidly $\left(\tau_{\text {des }}=3.0 \mathrm{~ms}\right.$ ). These kinetic properties are well characterized (Dingledine et al., 1999). In contrast, in a cell transfected with GluR1 plus stargazin, a higher current (801 pA) was 
Table 1. The electrophysiological properties of AMPA receptors without $\gamma 2$ and $\gamma 2$ mutants

\begin{tabular}{|c|c|c|c|c|}
\hline Construct & $n$ & Peak current (pA) & Steady state/peak (\%) & $\tau_{\text {des }}(\mathrm{ms})$ \\
\hline GluR1 & 23 & $599 \pm 130$ & $0.6 \pm 0.2$ & $3.0 \pm 0.2$ \\
\hline GluR1 plus $\gamma 2$ & 24 & $1061 \pm 194^{*}$ & $9 \pm 1^{* *}$ & $7.4 \pm 0.3^{* *}$ \\
\hline GluR1 plus $\gamma 2 \Delta$ PDZ & 9 & $1183 \pm 559$ & $9 \pm 2^{* *}$ & $8.3 \pm 1.1^{* *}$ \\
\hline GluR1 plus $\gamma 2 \Delta(265-323)$ & 4 & $939 \pm 447$ & $11 \pm 3^{* *}$ & $10.0 \pm 1.5^{* *}$ \\
\hline GluR1 plus $\gamma 2 \Delta(244-283)$ & 5 & $515 \pm 195$ & $14 \pm 4^{* *}$ & $10.0 \pm 2.0^{* *}$ \\
\hline GluR2 & 12 & $677 \pm 279$ & $4 \pm 1$ & $9.1 \pm 0.4$ \\
\hline GluR2 plus $\gamma 2$ & 11 & $1630 \pm 422$ & $27 \pm 4^{* *}$ & $19.2 \pm 1.3^{* *}$ \\
\hline GluR2 plus $\gamma 2 \Delta$ PDZ & 4 & $350 \pm 139$ & $14 \pm 2^{* *}$ & $17.8 \pm 1.5^{* *}$ \\
\hline
\end{tabular}

${ }^{*} p<0.05 ;{ }^{* *} p<0.001$ compared with AMPA receptor expressed without $\gamma 2$.

evoked by the same glutamate application that showed a 2.5 -fold decrease in the rate of the desensitization $\left(\tau_{\text {des }}=7.4 \mathrm{~ms}\right)$ and a $>50$-fold increase in the steady-state/peak ratio (Fig. $2 A$, gray trace). Such GluR1 current kinetics were reproducible in every transfected cell examined (Table 1). Consistent with the relative small increase in peak current, coexpression with stargazin slightly increased both total and surface protein levels (Fig. 2A, inset). In addition, recordings from HEK293 cells transfected with GluR2 in its unedited form, with and without stargazin, showed the same changes in the desensitization parameters as found for GluR1 (Fig. $2 B$ and Table 1).

Next to the desensitization, we also assessed the effect of stargazin on AMPA receptor deactivation and recovery form desensitization. As shown in Figure 2, $C$ and $D$, cotransfection of stargazin significantly (by threefold) slowed the deactivation rates of GluR1 in response to brief applications of glutamate $(1 \mathrm{~ms})$ and accelerated receptor recovery from desensitization by twofold. We conclude that the presence of stargazin allosterically potentiates GluR1- and GluR2-mediated currents.

\section{Neither the PDZ- nor the nPIST-binding domain of stargazin} is necessary for the effect on AMPA receptor desensitization

Until now, stargazin regulation of AMPA receptor function was proposed to include two distinct trafficking steps: transport to the cellular surface membrane and clustering/anchoring at the postsynaptic site (the latter function depends on stargazin binding with PSD-95, which is mediated by its C-terminal PDZbinding motif) (Chen et al., 2000; Schnell et al., 2002). Interestingly, a PSD-95-related protein, SAP90, was shown to decrease the desensitization of the kainate receptor GluR6 when coexpressed in HEK293 cells, and this effect was proposed to depend on SAP90-induced clustering of the GluR6 receptors (Garcia et al., 1998). To test whether the stargazin effect on AMPA receptor desensitization may also relay on its ability to surface cluster the receptors, GluR1 was coexpressed in HEK293 cells with either stargazin lacking the $\mathrm{C}$-terminal four amino acids constituting the PDZ-binding motif ( $\gamma 2 \Delta$ PDZ) (Chen et al., 2000; Schnell et al., 2002) or with stargazin lacking the C-terminal 59 amino acids ( $\gamma 2 \Delta 265-323)$, which includes part of the binding region for a Golgi-resident protein, nPIST (Cuadra et al., 2004). In addition, a mutant lacking the nPIST-binding site but containing the PDZbinding motif, $\gamma 2 \Delta 244-283$, was also tested. All three C-terminal deletions preserve the binding of stargazin with AMPA receptors (Chen et al., 2003). As summarized in Table 1, $\gamma 2 \Delta$ PDZ, $\gamma 2 \Delta 265-323$, as well as $\gamma 2 \Delta 244-283$ exerted a similar effect on GluR1 desensitization compared with wild-type $\gamma 2$, and the same result was also observed for GluR2 coexpressed with $\gamma 2 \Delta \mathrm{PDZ}$. Similar results were also found in oocytes (data not shown). Together, these data suggest that the effect of stargazin on AMPA receptor desensitization is attributable to direct stargazin-AMPA receptor binding.

\section{Discussion}

Activation of ionotropic receptors is followed by either deactivation attributable to ligand unbinding or desensitization caused by closing of the ion channel pore while the receptors remain in a ligand-bound state. AMPA receptors desensitize rapidly, on a millisecond time scale, suggesting that the rate of receptor desensitization affects the duration of EPSCs in response to synaptically released glutamate. Furthermore, the rate of AMPA receptor recovery from desensitization influences the frequency of the postsynaptic response to repetitive activation (Jones and Westbrook, 1996, and references therein). Structurally, AMPA receptor desensitization is tightly linked to the conformational state of the tetrameric receptor complex: loss of desensitization by the L-to-Y substitution (Stern-Bach et al., 1998) or CTZ (Patneau et al., 1993) promotes subunit dimerization at the interface between the ligand-binding S1-S2 domains (Sun et al., 2002; Horning and Mayer, 2004). These findings, together with previous work on conformational changes during ligand binding (Armstrong and Gouaux, 2000), led to a proposal that desensitization of AMPA receptors is mediated by intersubunit rearrangements that uncouple the effect of the closure of the S1-S2 ligand-binding core from the ion channel gate (Sun et al., 2002).

Here, we showed that coexpression of stargazin renders AMPA receptors more responsive to glutamate, by slowing their deactivation rate, reducing the rate and extent of desensitization, and accelerating their recovery to the unbound (activating) state. Because CTZ and the L-to-Y substitution both occluded the effect of stargazin coexpression, we propose that stargazin acts via a similar allosteric mechanism (i.e., by stabilizing the dimer interface between the S1-S2 domains).

The functional significance of the presented findings is accentuated by the previously described trafficking functions of stargazin: AMPA receptors are complexed with and anchored by stargazin (as well as by other TARPs) at the postsynaptic membrane (Chen et al., 2000; Schnell et al., 2002; Tomita et al., 2004). This indicates that the ion-channel functions of synaptic AMPA receptors are directly enhanced by stargazin/TARP binding. Intriguingly, it is not clear presently whether all or only some synaptic AMPA receptors are complexed with stargazin/TARPs. Thus, it is possible to speculate that selective expression of stargazin (e.g., in distinct cell types, in young vs adult synapses of a same cell type, or even at different synapses within one neuron) may regulate the overall strength of the postsynaptic response at excitatory synapses and possibly act as a novel mechanism for synaptic plasticity. 


\section{References}

Armstrong N, Gouaux E (2000) Mechanisms for activation and antagonism of an AMPA-sensitive glutamate receptor: crystal structures of the GluR2 ligand binding core. Neuron 28:165-181.

Ayalon G, Stern-Bach Y (2001) Functional assembly of AMPA and kainate receptors is mediated by several discrete protein-protein interactions. Neuron 31:103-113.

Burgess DL, Davis CF, Gefrides LA, Noebels JL (1999) Identification of three novel $\mathrm{Ca}^{2+}$ channel gamma subunit genes reveals molecular diversification by tandem and chromosome duplication. Genome Res 9:1204-1213.

Chen L, Chetkovich DM, Petralia RS, Sweeney NT, Kawasaki Y, Wenthold RJ, Bredt DS, Nicoll RA (2000) Stargazin regulates synaptic targeting of AMPA receptors by two distinct mechanisms. Nature 408:936-943.

Chen L, El-Husseini A, Tomita S, Bredt DS, Nicoll RA (2003) Stargazin differentially controls the trafficking of alpha-amino-3-hydroxyl-5methyl-4-isoxazolepropionate and kainate receptors. Mol Pharmacol 64:703-706.

Cuadra AE, Kuo SH, Kawasaki Y, Bredt DS, Chetkovich DM (2004) AMPA receptor synaptic targeting regulated by stargazin interactions with the Golgi-resident PDZ protein nPIST. J Neurosci 24:7491-7502.

Dingledine R, Borges K, Bowie D, Traynelis SF (1999) The glutamate receptor ion channels. Pharmacol Rev 51:7-61.

Garcia EP, Mehta S, Blair LA, Wells DG, Shang J, Fukushima T, Fallon JR, Garner CC, Marshall J (1998) SAP90 binds and clusters kainate receptors causing incomplete desensitization. Neuron 21:727-739.

Hamill OP, Marty A, Neher E, Sakmann B, Sigworth FJ (1981) Improved patch-clamp techniques for high-resolution current recording from cells and cell-free membrane patches. Pflügers Arch 391:85-100.

Hashimoto K, Fukaya M, Qiao X, Sakimura K, Watanabe M, Kano M (1999) Impairment of AMPA receptor function in cerebellar granule cells of ataxic mutant mouse stargazer. J Neurosci 19:6027-6036.

Horning MS, Mayer ML (2004) Regulation of AMPA receptor gating by ligand binding core dimers. Neuron 41:379-388.

Jonas P (1995) Fast application of agonists to isolated membrane patches. In: Single-channel recording, Ed 2 (Sakmann B, Neher E, eds), pp 231243. New York: Plenum.

Jones MV, Westbrook GL (1996) The impact of receptor desensitization on fast synaptic transmission. Trends Neurosci 19:96-101.

Klugbauer N, Dai S, Specht V, Lacinova L, Marais E, Bohn G, Hofmann F
(2000) A family of gamma-like calcium channel subunits. FEBS Lett 470:189-197.

Lerma J (1992) Spermine regulates $N$-methyl-D-aspartate receptor desensitization. Neuron 8:343-352.

Letts VA, Felix R, Biddlecome GH, Arikkath J, Mahaffey CL, Valenzuela A Bartlett II FS, Mori Y, Campbell KP, Frankel WN (1998) The mouse stargazer gene encodes a neuronal $\mathrm{Ca}^{2+}$-channel gamma subunit. Nat Genet 19:340-347.

O’Brien RJ, Xu D, Petralia RS, Steward O, Huganir RL, Worley P (1999) Synaptic clustering of AMPA receptors by the extracellular immediateearly gene product Narp. Neuron 23:309-323.

Patneau DK, Vyklicky Jr L, Mayer ML (1993) Hippocampal neurons exhibit cyclothiazide-sensitive rapidly desensitizing responses to kainate. J Neurosci 13:3496-3509.

Priel A, Silberberg SD (2004) Mechanism of ivermectin facilitation of human P2X4 receptor channels. J Gen Physiol 123:281-293.

Schnell E, Sizemore M, Karimzadegan S, Chen L, Bredt DS, Nicoll RA (2002) Direct interactions between PSD-95 and stargazin control synaptic AMPA receptor number. Proc Natl Acad Sci USA 99:13902-13907.

Shi S, Hayashi Y, Esteban JA, Malinow R (2001) Subunit-specific rules governing AMPA receptor trafficking to synapses in hippocampal pyramidal neurons. Cell 105:331-343.

Stern-Bach Y, Russo S, Neuman M, Rosenmund C (1998) A point mutation in the glutamate binding site blocks desensitization of AMPA receptors. Neuron 21:907-918.

Sun Y, Olson R, Horning M, Armstrong N, Mayer M, Gouaux E (2002) Mechanism of glutamate receptor desensitization. Nature 417:245-253.

Tomita S, Chen L, Kawasaki Y, Petralia RS, Wenthold RJ, Nicoll RA, Bredt DS (2003) Functional studies and distribution define a family of transmembrane AMPA receptor regulatory proteins. J Cell Biol 161:805-816.

Tomita S, Fukata M, Nicoll RA, Bredt DS (2004) Dynamic interaction of stargazin-like TARPs with cycling AMPA receptors at synapses. Science 303:1508-1511.

Zamanillo D, Sprengel R, Hvalby O, Jensen V, Burnashev N, Rozov A, Kaiser KM, Koster HJ, Borchardt T, Worley P, Lubke J, Frotscher M, Kelly PH Sommer B, Andersen P, Seeburg PH, Sakmann B (1999) Importance of AMPA receptors for hippocampal synaptic plasticity but not for spatial learning. Science 284:1805-1811. 